DOI: https://doi.org/10.31933/dijdbm.v2i3

Received: 15 March 2021, Revised: 20 February 2021, Publish: 25 April 2021

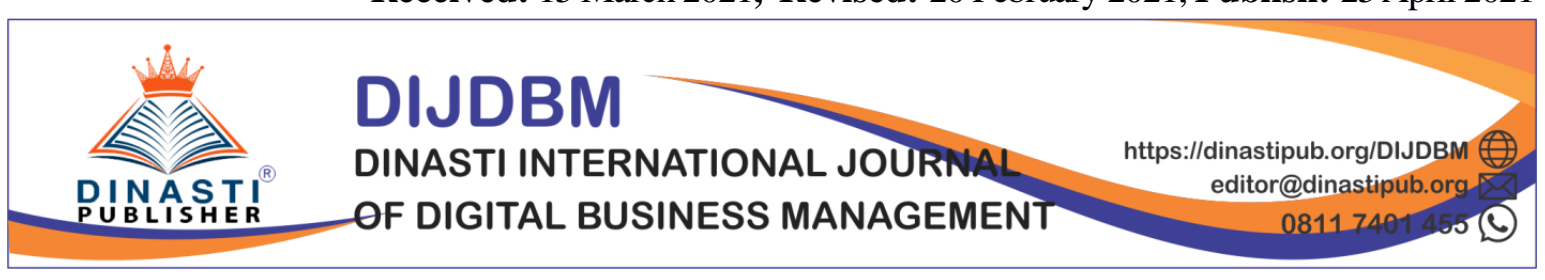

\title{
E-COMMERCE \& ONLINE MARKETING: RISKS ASSOCIATED WITH ONLINE SHOPPING
}

\author{
Devia Indriyani \\ Management Study Program, University of 17 August 1945 Cirebon Devia@ untagcirebon.ac.id
}

\section{Corresponding Author: First Author}

\begin{abstract}
In addition to shopping website, online Business also provides the organization with a lot of advertising opportunities web-based; the strategy to develop the market through online channels has lead to interest, and the seller to apply this strategy to improve their products and services. The use of the innovation (ie PC, Web) in online shopping or marketing to improve marketing operations. The trend of online shopping is becoming faster and faster. Now, the public perception about e-commerce has been adapted and consumers taking risks. In this study, the ideas of different researchers put forward. Researching the trends and status of women in the field of electronic commerce. It is believed that women in this era do very difficult shopping. The risk or the main factor that women prevent their online shopping is a factor of "trust". They just like to shop when they hear positive words from their family or their friends.
\end{abstract}

Keyword: Online shopping, E-Commerce, women, trust, risk, privacy, E-shopping

\section{INTRODUCTION}

In today's era, facts have proved that not only technological development is the current trend, but also the lifestyles of people and students today have become modern and trendy. They can communicate with each other using the latest communication and information technology. Since 2006, Indonesia's Internet development has accelerated rapidly, and the use of Internet media has also grown rapidly. It has now become the most important part of the economy and can also meet the needs of today's society and students. Affected by the Internet, even students and children have become active Internet users.

The advancement of information technology has led to a series of innovative activities in the economic field, especially the buying and selling of regular and online goods. If these activities were carried out in branches or stores in the past, they are now carried out online. These products take the form of goods and services, but the convenience of online shopping has increased the number of Internet users. According to a survey conducted by the Indonesian Internet Service Users Association, the number of people in the country is growing rapidly. In $2017,132.6$ million people $(54.86 \%$ of the Indonesian population) used the Internet to make a living, while in 2018 there were 171.17 million 
(64.8\%) users. (Widagdo \& Roz, 2021) Therefore, it is concluded that the number of Internet users detected each year has increased by $10 \%$. This has led to the emergence of online retail or more widely known as e-commerce, which is the way of life in today's society. However, with the rapid growth of online shopping, companies need to adopt specific strategies to maintain an important position in an already competitive market. A website created by the retail company can serve as the media for potential customers to interact and trade, making shopping easier. Use the methods of the Quality of the Web to measure the quality of the website. This is the development of service quality, which are widely used to capture consumer expectations and perceptions are assumed to represent the quality of the service (Baber, 2019). The success of online retail is determined by customer satisfaction after buying and selling activities(Machuca et al., 2007). During the recent period of time, due to the internet there have been tremendous changes in the way people live (Usak et al., 2020). Executive summary of a conference of the United united nations on trade and development (UNCTAD) stated that e-commerce will help improve the efficiency of trading by providing employment opportunities and increase the capacity of the wealth creating economy of developing countries around the world. ("E-Commerce and Development Report 2001," 2003).

Online business or Electronic Commerce is a new medium for doing business and digital marketing (Syazali et al., 2019). This has brought the online shopping and then change the method of ordinary shopping. Previously, people visited the shop physically touch the product they want to buy, ask for a discount from the seller, and with this way of buying products. Shopping the web-based new has changed the method of conventional shopping to the client to be the method is simple and convenient to take and pay for their items. The company wanted to strengthen yourself with a stay at the forefront, because the more difficult the competition among the competitors. Because of this, the organization of the previous decade trying to have a method of Online and offline Shopping, because it is a requirement to keep it updated this time. (Nazir \& Haq, 2018)

The e-commerce industry is the technology industry-an incentive. As part of the ICT industry, the creative industry is planned by the government to make major contributions to economic development. The ICT industry will be prioritized because the industry has a high growth rate or what is called the industrial future for Indonesia. In addition, it is also indicated by the experts which stated the need of a paradigm shift in the industry move from the product of the mass to the values of creative added.(Kim, 2002; Lucci, 2012)

Since the introduction of the Internet, privacy and security have been considered among the online business as the basic components required to provide and build online trust with online shoppers, and they are often cited as pioneers of online trust. There is a general understanding that the quality of the buyer (both demographic and personality) are assumed to have an important role in the promotion, because they give the opportunity to customize the goods, services, and other communication to better handle the needs and wishes of the buyer.(Riquelme \& Román, 2014)

In Indonesia, the Trade-e as the activity on the model of the economy that is supported by the infrastructure on the internet has a spacious room and implementation. Republic of the Technology of Communication and Information of Indonesia (2012) explains that if the infrastructure, connectivity, tend to change people's behavior, and ease- 
of-use activity support E-commerce e-commerce, then Indonesia will carry out the activities of e-commerce for anything.

With stable economic growth, a young population and the development of the middle class, manufacturers of consumer products have a positive outlook for the Indonesian market as the next big leap from an emerging market. With a larger base of consumers from the United States and Europe, the emerging market is a great opportunity as millions of people emerged from poverty to write and enter the middle class, with revenue growing to spend. Analysts claim that Indonesian consumers have characteristics in six areas: willingness to pay more for the brand, which is homogeneous in what they buy, strong brand loyalty, preference for small packaging, high frequency and is affected by social media (Suwastoyo, 2013). The advent of the awareness of the society using the technology of the internet or e-banking, developing the infrastructure of the internet, the increasing number of the middle class, increases education and gadgets an expanded users in Indonesia have a positive impact on the demand of the e-commerce industry.(Frost \& Sullivan, 2012) Starting in 2012, some sites Niaga Indonesia was established by Foreign Direct Investment (FDI) from multinational companies. This is insight into the ecommerce business in Indonesia who entered the leap of rapid growth. Based on the research background above, the formula issue research paper that guides the reader to understand clearly is that there are some factors of the external environment that creates opportunities, threats and business that will affect the location of the e-in Indonesia.

\section{RESEARCH METHODS}

This research was conducted on the online shopping experience of women, who belong to the age group of 15 years or older. The respondents including students, employers, employees and housewives, because the population is not known. Therefore, the approximate population of 1000 be considered and the sample size of 200 respondents was used in the survey, yielding a response rate of $90 \%$. The questionnaire developed was given the respondents were selected using the technique of comfort trial.

Data collection was done through questionnaires distribute directly to consumers who have online shopping experience. The questionnaire semi-structured explicitly intended with the end goal of this exam. It consists of closed questions, direct and indirect, contains the explanation of the social profile of the respondents which statistics; especially: sexual, salary, age, and orientation, and so on; this is followed by the statements relating to social media, payment methods used, the problem of security. The security of online shopping system is qualitative. Therefore, the response to this question qualitatively recorded on a five-point Likert scale ranging from strongly disagree to strongly agree. For measuring Construction (Security, Privacy), Some of the items designed by the researchers was used for the study. After a review of the literature, the construction site I selected. A grain is measured using a scale of five-point Likert scale ranging from (1) strongly disagree (5).

The Data were analyzed through frequency such as age, gender, designation, etc. to understand the profile of the respondents. A reason to like and don't like online shopping, and the source of the consumer use the most common to get the information about the product is also analyzed, together with the security of the payment system. To identify the relationship, correlation and regression analysis are used. 


\section{RESULTS}

Statistical package IBM for Social Science (SPSS) Version 18 was used to analyze the data (IBM, 2019). Relationships between variables were analyzed using several statistical techniques. Pearson correlation analysis was used to assess the linear relationship between two variables. Construction scattered and do not overlap as shown by the correlation coefficient which all construction tested not exceed 0.75 .

Table 1. Summary of the determinants of online consumer trust correlations

\begin{tabular}{|l|c|c|}
\hline Constructs & Statistics & Online Trust \\
\hline Perceived Security & Correlation & $\mathbf{0 . 7 4 0}$ \\
\hline & Sig. (2-tailed) & $\mathbf{0 . 0 0 0}$ \\
\hline Perceived Privacy & Correlation & $\mathbf{0 . 6 6 0}$ \\
\hline & Sig. (2-tailed) & $\mathbf{0 . 0 0 0}$ \\
\hline
\end{tabular}

Summary of the hypotheses is shown in Table 2 was conducted to assess and evaluate the level of influence of any construction on the dependent variable of consumer trust online. The hypothesis is confirmed because all constructs are statistically significant with p-value less than 0.05 .

Table 2. Summary of Hypothesis Test results

\begin{tabular}{|l|c|c|}
\hline \multicolumn{1}{|c|}{ Hypothesis } & Values Scored & Determination \\
\hline $\begin{array}{l}\text { H1: The perceived security of online } \\
\text { transactions will affect consumers' online } \\
\text { trust. }\end{array}$ & $\begin{array}{l}\mathrm{r}=0.744 \\
\mathrm{p}=0.000\end{array}$ & Supported \\
& $\mathrm{p}<0.05)$ & \\
\hline $\begin{array}{l}\text { H2: Perceived privacy of online transactions } \\
\text { will affect consumers' online trust }\end{array}$ & $\mathrm{r}=0.660$ & Supported \\
\hline
\end{tabular}

The purpose of regression analysis multiple is to predict a variable that depends on one by the set of independent variables. To test the hypotheses, multiple regression analysis and Pearson correlation analysis was performed. Tables 3 and 4 show the results of the analysis.

Table 3. Gradual Multiple Regression Analysis

\begin{tabular}{|c|c|c|c|c|c|c|}
\hline & \multirow[t]{2}{*}{\begin{tabular}{|l|} 
Model \\
\end{tabular}} & \multicolumn{3}{|c|}{$\begin{array}{c}\text { Unstandardized } \\
\text { Standardized } \\
\text { Coefficients Coefficients } \\
\text { B Std. Beta Error }\end{array}$} & \multirow[t]{2}{*}{$\begin{array}{c}\mathbf{t} \\
1,370 \\
\end{array}$} & \multirow[t]{2}{*}{$\begin{array}{l}\text { Sig. } \\
0.137 \\
\end{array}$} \\
\hline & & 0.375 & 0.264 & & & \\
\hline 1. & Perceived Security & 0.784 & 0.061 & 0.742 & 13,225 & 0.000 \\
\hline & (Constant) & -0.070 & 0.239 & & $-2,211$ & 0830 \\
\hline
\end{tabular}




\begin{tabular}{|r|l|l|l|r|r|l|}
\hline & Perceived Security & 0.680 & 0.060 & 0.570 & 10,222 & 0.000 \\
\hline 2 & Perceived Privacy & 0.350 & 0.057 & 0.405 & 7,210 & 0.000 \\
\hline & Constant) & -0.335 & 0.230 & & $-1,401$ & 0.175 \\
\hline & Perceived Privacy & 0.472 & 0.060 & 0.450 & 8,388 & 0.000 \\
\hline
\end{tabular}

Table 4. Power of Stepwise Regression of Relationships. Summary of the Model (Stepwise Method)

\begin{tabular}{|c|l|l|l|l|}
\hline Model & \multicolumn{1}{|c|}{$\mathbf{R}$} & \multicolumn{1}{|c|}{ R Square } & $\begin{array}{l}\text { Adjusted } \\
\text { Square }\end{array}$ & $\begin{array}{l}\text { Std. Error of } \\
\text { Estimate }\end{array}$ \\
\hline 1 & $0.733 \mathrm{a}$ & 0.555 & 0.552 & 0.910 \\
\hline 2 & $0.829 \mathrm{~b}$ & 0.675 & 0.668 & 0.795 \\
\hline 3 & $0.860 \mathrm{c}$ & 0.712 & 0.688 & 0.735 \\
\hline
\end{tabular}

The results of correlation analysis showed a significant positive effect on online trust value $\alpha=0.000 ; \mathrm{p}<0.05$, which confirms the hypothesis with the statistical evidence that is substantial. The highest value among the variables is the perception of security, which has a coefficient of regression of the standard $\beta$ 0.450. This shows that online consumers appreciate the security of online transactions that are perceived. After the test the correlation carried out for the variables privacy perceived, the value of $(\alpha)$ was 0,$000 ; p$ $<0.05$ was obtained. The test results show that privacy is perceived to have a significant positive effect on consumer trust online.

\section{DISCUSSION AND CONCLUSION}

These findings are consistent with the earlier discovery in which they stressed the importance of the privacy of feel in consumer confidence online inspire' (Bojang, 2017). It should be noted that the reputation of the company, structural best, and the feasibility of the trust, and the influence of initial consumer trust of the attitude of online shopping. We can also say that consumer confidence in online shopping is influenced by issues such as cost of shipping, privacy, and the inability to touch the product. However, people who believe that online transactions are not secure enough to protect the information of the payment was expressed and are likely to purchase the rush when the purchase will be other groups become online shoppers.(Suki \& Suki, 2013)

It is analyzed from the results that the online shopping is quite common among students and young people aged 20 to 30 years. Shopping site-based clients who have many of the issues of trust that shows the fear of losing money and anticipate the results of the quality that cannot be accepted. However, they think that shopping online is a comfortable way, but there are some risks associated with it such as theft of money, they also do not feel comfortable sharing their personal information on the internet, they are also almost giving up on the idea of shopping online if 'payment card' is the only option available for shopping. That's why, money Delivery is the most trusted and well-known 
among consumers are shopping online. To manage the concerns of the cash and the clients 'trust.

Discount simple and the exchange of goods and unconditional Covenant are some of the important elements which help improve the affirmation of the client as well as their opinions about the promotion of web-based. Website marketing system, a web-based, intended to attract clients in this way, that their first experience should be positive, it also helps create a loyal client. E-market is also useful in establishing the certainty of the clients by providing a choice of COD, which helps limit the danger signs of installation associated with the purchase request. The main source to get information for consumers is through social websites, because of the need to focus on their social sites to get more consumer traffic from there. But time savings, home delivery, ease of ordering some of the main factors which attract customers. However, privacy and lack of ability to physically see the product is a factor limitation. An experienced internet users and online buyers will likely be a buyer of the future online.

\section{REFERENCE}

Baber, H. (2019). E-SERVQUAL and Its Impact on the Performance of Islamic Banks in Malaysia from the Customer's Perspective. The Journal of Asian Finance, Economics and Business. https://doi.org/10.13106/jafeb.2019.vol6.no1.169

Bojang, I. (2017). Determinants of trust in B2C e-commerce and their relationship with consumer online trust: a case of Ekaterinburg, Russian Federation. Journal of Internet Banking and Commerce.

E-Commerce and Development Report 2001. (2003). Info - The Journal of Policy, Regulation and Strategy for Telecommunications. https://doi.org/10.1108/146366903322008278

Frost, \& Sullivan. (2012). Frost \& Sullivan: Indonesia ICT Outlook The Big Leap Ahead.

IBM. (2019). SPSS Software | IBM. On the IBM website.

Kim, YH (2002). Financing information technology diffusion in low- income Asian developing countries. Development Center Seminars Technology and Poverty Reduction in Asia and the Pacific, 115-133, 115-133.

Lucci, P. (2012). Post-2015 MDGs What role for business? Odi.

Machuca, JAD, González-Zamora, M. del M., \& Aguilar-Escobar, VG (2007). Service Operations Management research. Journal of Operations Management. https://doi.org/10.1016/j.jom.2006.04.005

Nazir, S., \& Haq, Z. (2018). Exploring Women's Attitude in Online Shopping- A review of Literature. International Journal of Enhanced Research in Management \& Computer Applications, 7 (3), 566-570. https://www.researchgate.net/profile/Salsabeel_Nazir/publication/324835442_Explori ng_Womens_attitude_in_Online_Shopping- 
A_review_of_Literature/links/5ba5e40892851ca9ed1c850c/Exploring-Women-Areview-in-Online-Shopping-A- $p$

Riquelme, IP, \& Román, S. (2014). Is the influence of privacy and security on online trust the same for all type of consumers. Electronic Markets, 24 (2), 135-149. https://doi.org/10.1007/s12525-013-0145-3

Suki, NM, \& Suki, NM (2013). Consumer Online Shopping Behavior: The Effect of Internet Marketing Environment, Product Characteristics, Familiarity and Confidence, and Promotional Offer. 7 (3), 814-819.

Suwastoyo. (2013). Retailers eye Indonesia as next big market. Jakarta Globe Magazine. https://retailinasia.com/in-markets/south-east-asia/indonesia/retailers-eye-indonesianext-big-market/

Syazali, M., Putra, FG, Rinaldi, A., Utami, LF, Widayanti, W., Umam, R., \& Jermsittiparsert, K. (2019). Partial correlation analysis using multiple linear regression: Impact on the business environment of digital marketing interest in the era of industrial revolution 4.0. Management Science Letters. https://doi.org/10.5267/j.msl.2019.6.005

Usak, M., Kubiatko, M., Shabbir, MS, Dudnik, OV, Jermsittiparsert, K., \& Rajabion, L. (2020). Health care service delivery based on the Internet of things: A systematic and comprehensive study. International Journal of Communication Systems. https://doi.org/10.1002/dac.4179

Widagdo, B., \& Roz, K. (2021). Hedonic Shopping Motivation and Impulse Buying: The Effect of Website Quality on Customer Satisfaction. Journal of Asian Finance, Economics and Business. https://doi.org/10.13106/jafeb.2021.vol8.no1.395 